\title{
"REPUBLIK HOT NGELESOT" SEBAGAI WUJUD PENERAPAN PROGRAM CYBER CITY PEMERINTAH DAERAH ISTIMEWA YOGYAKARTA (Studi Kasus Pada Program Cyber City Pemerintah Daerah Istimewa Yogyakarta)
}

\author{
Ita Suryani \\ Akademi Komunikasi Bina Sarana Informatika \\ e-mail: ita.its@bsi.ac.id
}

\begin{abstract}
Cyber city is one of the concepts of the modern city based information technology that recently has been applied in several big cities in the world. This concept is described as an area with information technology infrastructure both with integrated connecting-web, bandwith capacity, wireless and cable internet, and Wi-Fi (wireless fidelity) hotspot installation in some open spaces such as in the cityparks, sports arena, airports, harbour, bus terminal, shopping center, and tourist places. Yogyakarta, one of provinces in Indonesia, for example, its society is booming with hotspot. This facility is available everywhere, such as in the campus, school, offices, and local culinary places (angkringan). Thus, recently Yogyakarta is known as "Republik Hot Ngelesot" city. The aims of this research is to know how the application of cyber city program is, which Yogya named it with "Republik Hot Ngelesot". Methods used in this research is case study; it is the research method that uses many data sources which is used to analyze the research comprehensively from individual and group aspect, program, organization or events sistematically. Results show that "Republik Hot Ngelesot" is one of cyber city program implementions in Yogyakarta. It purposes to make easy Yogya's society because basically by using internet technology, the society can get public service easily in daily life, especially in economy, social, culture, and education aspects.
\end{abstract}

Keywords : information communication technology, internet, cyber city

\begin{abstract}
ABSTRAK
Cyber city merupakan salah satu konsep kota modern berbasis teknologi informasi yang kini telah banyak diterapkan di sejumlah kota besar di seluruh dunia. Konsep cyber city digambarkan sebagai kawasan dengan infrastruktur teknologi informasi yang memadai baik dari sisi konektivitas jaringan terpadu, kapasitas bandwidth, internet nirkabel dan kabel serta pemasangan hotspot Wi-Fi (wireless fidelity) di sejumlah tempat terbuka seperti taman kota, tempat olahraga, bandara, pelabuhan, terminal bis, pusat perbelanjan modern dan tempat-tempat wisata. Seperti yang terjadi pada Pemerintah Daerah Istimewa Yogyakarta, dimana saat ini masyarakatnya sedang mengalami demam hotspot. Fasilitas hotspot disediakan di mana-mana, mulai kampus, sekolah, perkantoran, hingga tempat kuliner seperti angkringan. Maka saat ini kota Yogya telah berkembang sebagai Ibukota "Republik Hot Ngelesot". Tujuan penelitian ini yaitu ingin mengetahui bagaimana wujud penerapan program cyber city pemerintah kota Yogya yang diistilahkan dengan "Republik Hot Ngelesot". Metode yang digunakan dalam penelitian ini yaitu metode studi kasus yaitu metode riset yang menggunakan berbagai sumber data yang bisa digunakan untuk meneliti, menguraikan dan menjelaskan secara komprehensif berbagai aspek
\end{abstract}


individu, kelompok, suatu program, organisasi atau peristiwa secara sistematis. Kesimpulan menunjukan bahwa "Republik Hot Ngelesot" merupakan salah satu wujud penerapan Program Cyber City Pemerintah Daerah Istimewa Yogyakarta (DIY), dengan tujuan mempermudah masyarakat kota Yogya, karena pada dasarnya melalui teknologi internet, masyarakat bisa mendapatkan kemudahan pelayanan publik dalam kehidupan sehari-hari, baik itu di bidang ekonomi, sosial, budaya, dan pendidikan.

\section{Kata kunci : Teknologi Informasi Dan Komunikasi, Internet, Cyber City}

\section{PENDAHULUAN}

Kebutuhan masyarakat akan ilmu pengetahuan dan teknologi (iptek) semakin lama semakin tinggi. Saat ini, pengetahuan telah menjadi faktor penting penentu standar hidup manusia. Pertumbuhan penduduk yang terus meningkat memiliki pengaruh terhadap perkembangan suatu wilayah. Salah satu faktor pendorong pertumbuhan wilayah yaitu teknologi. Pengembangan ICT (Information

Communication

Technology) di suatu wilayah tentunya mampu mendorong pertumbuhan wilayah karena dengan adanya teknologi mampu meningkatkan produktivitas manusia dalam melakukan kegiatannya.

Pembangunan suatu wilayah yang dipengaruhi faktor teknologi umumnya terjadi di kawasan perkotaan. Pemerintah menerapkan cyber city dalam manajemen perkotaan sebagai konsep kota masa depan yang berbasis teknologi. cyber city ini merupakan salah satu usaha pemerintah untuk meningkatkan kualitas masyarakat serta memenuhi kebutuhan masyarakat dalam hal teknologi informasi. Ke depannya, manusia akan semakin bergantung pada iptek dalam aktivitasnya. Cyber city ini dapat membantu masyarakat mempermudah aktivitasnya dengan adanya layanan internet secara lebih luas dan tidak terbatas (Aprilia, Jurnal Bumi Indonesia, 2013:278).

Menerapkan konsep cyber city di Indonesia bertujuan untuk memenuhi kebutuhan warganya dalam mengakses internet secara lebih luas dan tidak lagi terbatas pada kalangan tertentu saja. Bagaimanapun juga bangsa Indonesia kini berada dalam abad informasi dimana setiap orang memiliki peluang yang sama untuk menjalin pergaulan secara luas baik nasional maupun internasional. Implementasi cyber city juga bisa membantu masyarakat dalam memanfaatkan kecanggihan teknologi informasi. Dalam hal ini, masyarakat akan semakin pandai menggunakan internet dalam jumlah yang besar. Pemasangan hot spot Wi-Fi di sejumlah tempat terbuka seperti taman-taman 
kota, tempat-tempat olahraga, lokasi bandara, pelabuhan, terminal bis, pusatpusat perbelanjaan modern dan tempattempat wisata lainnya akan semakin memudahkan masyarakat untuk beraktifitas secara lebih leluasa dalam satu waktu yang bersamaan.

Berwisata sambil berkirim email, menyantap makanan sambil mengerjakan tugas kantor, duduk di kendaraan sambil chatting dengan kolega dan sebagainya adalah contohcontoh aktifitas yang sering dijumpai di tengah masyarakat, khususnya di kotakota besar di Indonesia. Pendeknya, aktifitas apapun yang dilakukan tidak akan mengganggu pekerjaan inti di kantor. Model kerja dinamis seperti ini sedang menjadi tren di tengah masyarakat dimana mobilitas kaum profesional, pebisnis, pendidik termasuk juga para mahasiswa semakin tinggi. Bekerja secara parallel mungkin itu istilah yang paling tepat bagi anggota masyarakat di berbagai kota besar di Indonesia.

Mulai dari sekadar mengakses informasi biasa hingga melakukan berbagai jenis transaksi bisnis sudah dapat dilakukan via internet termasuk di dunia pendidikan, perbankan, ketenagakerjaan dan sebagainya. Internet yang multifungsi ini perlahan tapi pasti berusaha mengubah perilaku atau budaya sebagian besar warga kota dari pola-pola layanan konvensional menjadi layanan yang serba digital dan instant. Dengan kelebihannya itu pula, internet diprediksikan akan semakin diminati masyarakat sejalan dengan meningkatnya kebutuhan dan perkembangan teknologi informasi. Belakangan ini, cukup ramai terlihat sejumlah gubernur, bupati, walikota, maupun industri serta komunitas diberbagai belahan nusantara yang secara sadar, bersemangat, dan kolektif mencanangkan misi pembentukan cyber province, cyber city di daerahnya masing-masing. Tentu saja hal ini patut disambut gembira oleh seluruh praktisi TIK (Teknologi Informasi dan Komunikasi) di tanah air karena adanya keinginan untuk menerapkan teknologi informasi dan komunikasi sebagai upaya meningkatkan daya saing daerah pada khususnya dan Indonesia pada umumnya.

Merujuk pada uraian diatas, maka cyber city merupakan salah satu konsep kota modern berbasis teknologi informasi yang kini telah banyak diterapkan di sejumlah kota besar di seluruh dunia. Ini adalah konsekuensi logis dari meningkatnya kebutuhan masyarakat yang ingin mengakses informasi dan berkomunikasi dengan mudah dan cepat 
(http://id.wikipedia.org/wiki/cyber_city)

Dalam berbagai sektor, penggunaan teknologi memberikan pengaruh yang sangat besar karena mempermudah dalam aktivitas masyarakat. Seperti yang terjadi pada pemerintah Daerah Istimewa Yogyakarta, saat ini warga Yogya sedang mengalami demam hotspot. Fasilitas hotspot disediakan di manamana, mulai tempat kerja, kampus, sekolah, taman kanak-kanak, kedai, koskosan, arena futsal, hingga angkringan.

Dalam rangka mewujudkan visi misi kota Yogyakarta, beberapa terobosan terus dikerjakan Pemerintah dan salahsatunya pengembangan Kota Yogya sebagai cyber city. cyber city yang akan dikembangkan di kota Yogya ini merupakan pengembangan model kota ekowisata yang berbasiskan teknologi informasi. Pengembangan dengan teknologi informasi ini diharapkan dapat menggenjot aspek kepariwisataan, komunikasi lintas instansi yang akan berdampak pada perkembangan perekonomian kota Yogya juga akses informasi kepada publik.

Maka dari itu, untuk menciptakan Cyber City di Yogyakarta diperlukan jaringan internet khususnya berbasis $W i$ $F i$ atau hotspot, yang ditempatkan di tempat terbuka, seperti taman kota, tempat rekreasi, tempat olahraga, pelabuhan, bandara, terminal, pusat perbelanjaan modern, dan tempat wisata. Hal ini agar dapat memudahkan masyarakat dalam mengakses informasi yang dibutuhkan.

Berdasarkan alasan tersebut, penulis tertarik membahas mengenai “Republik Hot Ngelesot” Sebagai Wujud Penerapan Program Cyber City Pemerintah Daerah Istimewa Yogyakarta (DIY).

Revolusi di bidang teknologi informasi dan komputer (TIK) berimplikasi terhadap kegiatan manusia di segala bidang. Saat ini telah menjamur adanya fasilitas hotspot di tempat-tempat umum wilayah Yogyakarta, karena itulah warga Yogya mengistilahkan kota Yogya dengan "Republik Hot Ngelesot". Berkaitan dengan apa yang melatarbelakangi hal tersebut, maka peneliti membuat rumusan masalah sebagai berikut : "Bagaimana wujud penerapan program cyber city pemerintah Kota Yogya yang diistilahkan dengan "Republik Hot Ngelesot?".

\section{KERANGKA PEMIKIRAN}

Teknologi Informasi Dan Komunikasi

TIK merupakan sekumpulan teknologi dan aplikasinya terkait dengan 
proses elektronik, penyimpanan dan pemindahan informasi untuk penggunaan yang bervariasi (Cohen dkk, 2002 dalam Rachmawati, 2011:56). Karakteristik dari TIK adalah : (1) sangat dinamis terhadap perubahan, (2) menurunkan biaya, (3) aplikasi dan penetrasi TIK dalam banyak bidang terkait dengan profesi dan gaya hidup meningkat secara cepat, dan (4) diperlukan kualitas keterampilan sumberdaya manusia dalam mengoperasikan TIK.

Beberapa jenis TIK adalah telephone, handphone (mobile phone), faximile, komputer dan internet. Teknologi informasi dapat meliputi seluruh komponen yang berbasis informasi, digerakkan oleh komputer, dan komuniasi berkaitan dengan aktivitas (Knox dan Marston, 2004 dalam Rachmawati, 2011:56).

Menurut Indrajit (2000:45), teknologi informasi dan komunikasi adalah teknologi yang berhubungan dengan pengolahan sumber data menjadi informasi dan disalurkan dalam batasan ruang dan waktu melalui teknologi alat bantu untuk memproses/mentransfer data dari satu perangkat ke perangkat lainnya. Teknologi informasi dan komunikasi memiliki kemampuan untuk mengalami proses pertukaran data dan informasi seiring dengan inovasi dan perkembangan teknologi informasi dan komunikasi itu sendiri.

\section{Pemanfaatan Teknologi Informasi Dan Komunikasi}

Menurut Wardianna (2002) dalamRachmawati (2011:58), pada era pemanfaatan teknologi informasi dan komunikasi, jarak fisik atau jarak geografis tidak lagi menjadi faktor penghubung antara manusia satu dengan yang lainnya atau lembaga usaha sekalipun, jagad ini menjadi sebuah dusun semesta atau global village dimana sering diistilahkan dengan “jarak sudah mati” (distance is dead). Pemanfaatan TIK semakin mempermudah akses untuk mencapai dan berbagi sesuatu. Kehadiran sistem $e$ learning, e-commerce, e-banking, egovernment dan lain sebagainya menghadirkan suatu sistem baru dalam kehidupan manusia yang dapat dimanfaatkan dimana saja dan kapan saja selama terhubung dengan teknologi informasi dan teknologi komunikasi itu sendiri.

Kehadiran teknologi dan informasi memberikan pengaruh terhadap gaya hidup dan pola berpikir seseorang. Perkembangan teknologi informasi mengalami perkembangan yang sangat pesat bagi masyarakat perkotaan dan menjadi gaya hidup high-technology 
(Knox dan Marston, 2004 dalam Rachmawati, 2011:58).

\section{Internet}

Internet adalah merupakan jaringan dari ribuan jaringan komputer yang menjangkau jutaan orang di seluruh dunia (LaQuery, 1997). Pendapat ini menunjukkan bahwa internet merupakan suatu jaringan internasional atau mancanegara yang menghubungkan jutaan komputer di dunia. Pendapat lain menyatakan bahwa internet adalah sistem komputer yang saling berhubungan, sehingga memungkinkan komputer desktop yang kita miliki dapat bertukar data, pesan, dan file-file dengan berjuta-juta komputer lain yang berhubungan ke internet (Allen, 1997). Kedua definisi di atas memberikan pemahaman yang sangat mendasar, bahwa berbicara tentang internet objeknya adalah komputer, jaringan dan perangkat lainnya (hardware dan software).

Koesnandar (2008:12) dalam Suroso dan Adi Winanto (2009:3) menjelaskan bahwa internet mempunyai peran yang besar dalam pembelajaran, yaitu sebagai referensi ilmu pengetahuan terkini, alat manajemen pengetahuan, jaringan pakarberagam ilmu, jaringan antar institusi pendidikan, pusat pengembangan materi ajar, wahana pengembangan kurikulum, dan komunitas perbandingan standar kompetensi. Hal yang disayangkan adalah banyak kalangan remaja khususnya parasiswa belum mengoptimalkannya sebagai sumber belajar.

Ferguson \& Perse (2000) dalam Giles (2003:267) menemukan bahwa para remaja tidak menggunakan internet untuk kepentingan pencarian informasi tentang pelajaran. Young (1998) dan Griffiths (1999) dalam Giles (2003:268) menemukan bahwa penggunaan internet yang berlebih ditujukan lebih banyak untuk kepentingan penjalinan hubungan sosial dari pada pengumpulan informasi tentang pelajaran.

\section{Cyber City}

Cyber City sebagai sebuah kota yang berbasiskan jaringan, dimana jaringan tersebut dapat memberikan pelayanan kepada publik untuk menciptakan nilai sosial-ekonomi bagi para pelaku bisnis serta masyarakat (Dameri dalam Deakin, 2014:39). Konsep cyber city merupakan konsep pembangunan sebuah lingkungan dimana orang yang berada di kawasan regional dapat berinteraksi dan berbagi pengetahuan, pengalaman, dan kepentingan bersama. Selain itu, fungsi konsep cyber city untuk 
mengintegrasikan informasi perkotaan dan menciptakan ruang publik melalui sebuah jaringan internet untuk masyarakat yang tinggal atau mengunjungi kota. Dengan konsep cyber city sebuah kota dapat meringkas (seperti data, informasi, layanan publik, dan lain sebagainya) untuk memudahkan setiap orang dalam mengambil keputusan (Ishida dan Hiramotsu dalam Deakin, 2014:39)

Penerapan cyber city mampu membangun image baru kota tersebut sebagai kota yang berbasis ICT. Image tersebut dapat dibangun melalui pengembangan industri-industri berbasis ICT sehingga dapat menjadi daya tarik bagi pengusaha atau investor untuk menanamkan modalnya di industri tersebut dan membuka lapangan kerja bagi masyarakat kota tersebut. Seperti singapura, memiliki inisiatif untuk membangun singapura sebagai negara IT terbesar. Negara ini sudah memiliki komunitas bisnis IT yang sangat baik, dan berencana untuk memperluas ke industri ICT bahkan di singapura saat ini sudah memiliki industri animasi yang namanya sudah mendunia dan karyakaryanya sudah banyak di lirik oleh perusahaan-perusahaan animasi di Amerika dan Eropa (McCurtis dan Wimberly, 2002:64).(McCurtis \& Wimberly)
Cyber city menunjukkan daerah yang broadband infrastruktur komunikasi yang fleksibel dengan sistem komputasi yang berorientasi pada layanan. Infrastruktur ini berusaha untuk memastikan pelayanan yang baik bagi pemerintah, masyarakat, konsumen, industri dan bisnis di kawasan tertentu (komninos dalam Deakin, 2014:46)

Tujuan cyber city adalah menciptakan lingkungan untuk berbagi informasi, berbagi pengalaman dan berkolaborasi bagi semua penghuni yang ada di kota tersebut. Untuk mencapai tujuan tersebut sebuah kota yang harus memiliki rencana dan menetapkan tujuan kebijakan publik untuk memberdayakan warganya agar memiliki akses ke jaringan informasi global dengan menggunakan fasilitas publik serta bermitra dengan perusahaan swasta untuk mencapai tujuan tersebut (Yovanof dan Hazapis dalam Deakin, 2014:48).

Salah satu alasan sebuah daerah menerapkan konsep cyber city dalam strategi pengembangan wilayahnya adalah untuk meningkatkan keunggulan kompetitif daerah, isu keunggulan kompetitif daerah sangat relevan mengingat kondisi dari setiap daerah yang tidak sama dapat menimbulkan kesenjangan sosial maupun ekonomi. Dengan melakukan investasi dalam 
bentuk infrastruktur cyber diharapkan investasi tersebut dapat menarik investor untuk menanamkan modalnya di kota tersebut, hal tersebut menjadi salah satu strategi untuk membentuk keunggulan kompetitif suatu wilayah. (McCurtis dan Wimberly, 2002:67).

\section{TUJUAN PENELITIAN}

Tujuan yang ingin dicapai penulis dalam mengangkat tema ini adalah ingin memperoleh gambaran mengenai bagaimana penerapan program Cyber City Kota Yogya yang diistilahkan dengan "Republik Hot Ngelesot".

\section{METODE PENELITIAN}

Metodologi pada penelitian ini yaitu metode studi kasus. Menurut Kriyantono (2006:66), metode studi kasus yaitu metode riset yang menggunakan berbagai sumber data yang bisa digunakan untuk meneliti, menguraikan dan menjelaskan secara komprehensif berbagai aspek individu, kelompok, suatu program, organisasi atau peristiwa secara sistematis.

Studi kasus adalah metode riset yang menggunakan berbagai sumber data (sebanyak mungkin data) yang bisa digunakan untuk meneliti, menguraikan, dan menjelaskan secara komprehensif berbagai aspek individu, kelompok, suatu program, organisasi atau peristiwa secara sistematis. Penelaahaan berbagai sumber data ini membutuhkan berbagai macam instrumen pengumpulan data. Karena itu, periset dapat menggunakan wawancara mendalam, observasi partisipan, dokumentasi-dokumentasi, kuesioner (hasil survei), rekaman, buktibukti fisik lainnya (Kriyantono, 2006: $65)$.

Sementara itu, Yin (2006:18) memberi batasan mengenai studi kasus sebagai riset yang menyelidiki fenomena di dalam konteks kehidupan nyata, bilamana batas-batas antara fenomena dan konteks tak tampak dengan jelas, dan di mana multisumber dimanfaatkan.

Penggunaan metode studi kasus pada pembahasan jurnal ini adalah studi kasus dengan fokus pada bagaimana penerapan cyber city di kota Jogya yang diistilahkan dengan "Republik Hot Ngelesot". Penggunaan studi kasus sebagai metode penelitian dikarenakan penelitian ini bertujuan memberikan uraian secara lengkap dan mendalam mengenai penerapan cyber city di kota Jogya.

Studi kasus adalah metode riset yang menggunakan berbagai sumber data (sebanyak mungkin data) yang bisa digunakan untuk meneliti, menguraikan, dan menjelaskan secara komprehensif berbagai aspek individu, kelompok, suatu program, organisasi atau peristiwa 
secara sistematis. Penelaahaan berbagai sumber data ini membutuhkan berbagai macam instrumen pengumpulan data. Karena itu, periset dapat menggunakan wawancara mendalam, observasi partisipan, dokumentasi-dokumentasi, kuesioner (hasil survei), rekaman, buktibukti fisik lainnya (Kriyantono, 2006: $65)$.

Data yang diperoleh akan dianalisis secara kualitatif yaitu analisis yang dilakukan dengan memahami dan merangkai data yang telah dikumpulkan dan disusun secara sistematis, kemudian ditarik kesimpulan.

Menurut Pawito (2008:102) bahwa dalam penelitian kualitatif, kesimpulan yang dihasilkan pada umumnya tidak dimaksudkan sebagai generalisasi, tetapi sebagai gambaran interpretatif tentang realitas atau gejala yang diteliti secara holistik dalam setting tertentu. Di sini, dikandung arti bahwa temuan apapun yang dihasilkan pada dasarnya bersifat terbatas pada kasus yang diamati. Oleh karena itu, prinsip berfikir induktif lebih menonjol dalam penarikan kesimpulan dalam penelitian komunikasi kualitatif.

Menurut Bogdan \& Taylor dalam Ruslan (2010:215), metode kualitatif diharapkan mampu menghasilkan suatu uraian mendalam tentang ucapan, tulisan, dan tingkah laku yang dapat diamati dari suatu individu, kelompok, masyarakat, organisasi tertentu dalam suatu konteks setting tertentu yang dikaji dari sudut pandang yang utuh, komprehensif dan holistic.

Berdasarkan tataran atau cara menganalisis data, penelitian ini termasuk dalam jenis penelitian deskriptif. Sejalan dengan hal tersebut, Moleong (2002: 11) mengemukakan bahwa salah satu karakteristik dalam penelitian kualitatif adalah deskriptif. Dalam hal ini data yang dikumpulkan berupa kata-kata, gambar dan bukan angka-angka. Hal ini disebabkan oleh adanya penerapan metode kualitatif. Selain itu, semua yang dikumpulkan berkemungkinan menjadi kunci terhadap apa yang sudah diteliti. Dengan demikian, laporan penelitian akan berisi kutipan-kutipan data untuk memberi gambaran penyajian laporan tersebut.

Data yang diambil peneliti dalam penulisan ini di dapat melalui studi kepustakaan atau sumber tertulis (library research). Secara umum definisi studi kepustakaan adalah usaha yang dilakukan oleh peneliti untuk menghimpun informasi yang relevan dengan topik atau masalah yang akan atau sedang diteliti. Informasi itu dapat diperoleh dari buku-buku ilmiah, laporan penelitian, karangan-karangan ilmiah, tesis dan disertasi, peraturan-peraturan, ketetapan-ketetapan, buku tahunan, 
ensiklopedia dan sumber-sumber tertulis baik tercetak maupun elektronik lainnya.

Menurut Ruslan (2010:31), riset kepustakaan adalah riset yang dilakukan untuk mencari data atau informasi riset melalui menbaca jurnal ilmiah, bukubuku, referensi dan bahan-bahan publikasi yang tersedia diperpustakaan".

Data-data yang digunakan dalam pembahasan jurnal ini yaitu data secara studi pustaka dan wawancara dengan nara sumber yang relevan dengan pembahasan dan data terkait Program Cyber City "Republik Hot Ngelesot" Pemerintah Daerah Yogyakarta.

\section{HASIL DAN PEMBAHASAN}

TIK membawa dampak yang positif bagi kemudahan manusia dalam berkomunikasi dan kualitas sumberdaya manusia karena persebaran informasi yang semakin cepat. Perkembangan TIK memberikan pengalaman baru dalam berkomunikasi bagi manusia diseluruh penjuru dunia tanpa batasan jarak dan waktu.

Dalam aktivitas manusia seharihari, tidak lepas dari terpaan TIK, baik dalam kegiatan belajar, hubungan antarbudaya, pemerintahan, dan berbagai aspek lainnya. Di lain pihak, perkembangan dunia yang sangat pesat dengan mobilitas dan dinamika yang sangat tinggi, dituntut sumber daya manusia sebagai penggerak inovator untuk siap menghadapi situasi-situasi baru dalam konteks interaksi dan interelasi yang saling melengkapi. Perkembangan tersebut, telah membuka mata dunia akan efisiensi dan efektivitas dalam berkomunikasi dan pencarian informasi.

Di pemerintahan misalnya, untuk menunjang good governance, diperlukan transparansi, akuntabilitas, dan aksesibilitas dalam mempercepat proses komunikasi dan informasi antara pemerintah dengan masyarakat, di mana pemanfaatan TIK ditujukan dalam rangka meningkatkan kualitas pelayanan publik.

Internet bak jendela dunia, kemana pun dan kapan pun kita ingin melihat berbagai belahan dunia dengan sekejap kita bisa berselancar melalui akses internet. Tentunya selama jaringan internet itu mumpuni dan memadai. Melihat begitu banyaknya manfaat internet, beberapa negara berusaha mewujudkan cyber city, sebut saja India, China dan Indonesia. Atas dasar kemudahan itulah, banyak warga Indonesia termasuk masyarakat Kota Yogya yang memanfaatkan akses internet untuk mengetahui berbagai informasi internasional.

Istilah cyber biasa digunakan untuk menyatakan sesuatu yang 
berhubungan dengan internet atau dunia maya. Hal itu tentunya berkaitan erat dengan TIK yang juga terkait erat dengan sebuah piranti canggih yaitu komputer, baik personal computer (PC), laptop/notebook maupun smart phone.

Jadi istilah cyber city dapat diartikan sebagai Kota Maya atau Kota yang semua warganya sudah "internet minded". Dapat disebut juga bahwa cyber city adalah istilah untuk sebuah kota yang sudah memanfaatkan teknologi informasi untuk menjalankan pemerintahannya, sekaligus menyediakan akses ke jaringan dan infrastruktur berbasis internet untuk seluruh masyarakatnya.

Daerah Istimewa Yogyakarta (DIY) adalah sebuah daerah otonomi setingkat propinsi di Indonesia dengan ibukota propinsinya adalah Yogyakarta, sebuah kota dengan berbagai predikat, baik dari sejarah maupun potensi yang ada, seperti sebagai kota perjuangan, kota kebudayaan, kota pelajar, dan kota pariwisata.

Untuk mewujudkan program Yogyakarta cyber city diperlukan koneksi jaringan yang terintegrasi seluruh kegiatan di lingkungan pemerintahan hingga ke tingkat kecamatan sehingga saling terhubung secara online. Salah satu tujuannya adalah dalam rangka meningkatkan pemerintahan yang baik (good government), dengan mengoptimalkan media online sebagai media informasi dan komunikasi. Konsep Yogya cyber city yang bertujuan mempermudah masyarakat Yogya, pada dasarnya melalui teknologi internet, masyarakat bisa mendapatkan kemudahan pelayanan publik dan dapat mengakses informasi yang disesuaikan dengan kebutuhannya.

Cyber city merupakan sebuah konsep kota masa depan yang berbasis dengan teknologi informasi tingkat lanjut. Sebuah kota dengan konsep cyber city akan menjadikan sebuah kota yang terkoneksi di seluruh bidang. Kecanggihan teknologi itu lah yang digunakan Pemerintah Kota Yogya dalam menjalankan pemerintahan dan melayani masyarakat serta kebutuhan masyarakat dalam memenuhi kebutuhan informasi yang diperlukan dalam kehidupan sehari-hari. Baik itu di bidang ekonomi, sosial, budaya, dan pendidikan.

Oleh karena itu, Pemerintah Propinsi DIY bersama PT Telekomunikasi Indonesia, Tbk (Telkom) melakukan penandatanganan Memorandum of Understanding (MoU) tentang pemanfaatan TIK untuk mewujudkan program Digital Government Services. 
Penandatanganan dilakukan oleh Direktur Utama Telkom Arief Yahya bersama Gubernur Daerah Istimewa Yogyakarta Sultan Hamengku Buwono $\mathrm{X}$. Pada kegiatan penandatanganan $\mathrm{MoU}$ sekaligus dilaksanakan kick off Yogya cyber city melalui pemasangan akses wifi (Indonesia Wifi) di sepanjang jalan Malioboro, Yogyakarta.

Menurut Haryanta, SH., selaku kepala Biro Umum, Hubungan Masyarakat dan Protokol " dalam mendukung visi pemerintah DIY sebagai daerah yang berkarakter, berbudaya, maju, mandiri dan sejahtera menyongsong peradaban baru, peresmian penggunaan akses internet di Malioboro merupakan awal dari pekerjaan besar, yakni mewujudkan DIY sebagai Digital Government Services pada akhir 2017.

"Terkait penyiapan akses Internet melalui Indonesia Wifi, saat ini terdapat tidak kurang dari 50 accesspoint Indonesia Wifi di sepanjang Jalan Malioboro, sedangkan di seluruh Yogyakarta saat ini sudah terpasang sekitar 1000 access point".

Pemerintah Kota Yogyakarta yang mengusung konsep Yogya Cyber City dengan istilah "Republik Hot Ngelesot" telah berkembang juga pada bidang pelayanan publik masyarakat. Istilah "Republik Hot Ngelesot" berasal dari banyaknya tempat-tempat keramaianseperti mall, taman bacaan, taman budaya, taman kota, sekolah, kantor bahkan sampai dengan angkringan yang menjadi tempat kuliner atau sekedar mengobrol. "Hot Ngelesot" sendiri diistilahkan oleh orang-orang Yogya yaitu fasilitas hotspot bisa digunakan sambil ngelesot atau lesehan di lantai, dimana saat ini orang-orang Yogya sedang demam hotspot.

"Penerapan program cyber city di kota Yogya, sangat memberikan manfaat dan dampak positif bagi masyarakat Kota Yogya antara lain dalam bidang ekonomi dan sosial yaitu sebagai contoh terdapatnya kampung cyber, bertempat persis di pelataran komplek wisata pemandian Taman Sari, Yogyakarta. Kampung ini merupakan contoh objek wisata daerah yang terletak di luar Yogyakarta yang ingin menjadikan cyber city bagi kotanya”.

Julukan Kampung cyber bukan hanya slogan agar warga kampung RT.36, RW.09, Taman, Kelurahan Pakelan, Kecamatan Kraton ini melek teknologi. Tetapi sebagai identitas kampung. Di gagas pada tahun 2009, 
dengan modal gotong-royong, kampung ini berhasil mewujudkan jaringan internet ke rumah-rumah dengan biaya yang murah tiap bulannya yaitu hanya dikenakan biaya sebesar Rp. 40.000 per bulan. Dengan adanya jaringan internet tersebut, segala kegiatan dan informasi yang berkaitan dengan kampung, warga bisa mengaksesnya langsung di situs yang bernama "RT36Kampoengcyber".

Situs "RT36Kampoengcyber" dimanfaatkan warga untuk mempromosikan potensi usaha para warga Kampung Taman, seperti usaha batik, online shop, dan pendidikan. Semua warga kampung sudah tak asing lagi dengan internet, mulai dari anakanak sampai usia lanjut memiliki akun jejaring sosial. Selain itu, penerapan cyber city juga dimanfaatkan oleh para pebisnis atau pelaku usaha seperti warnet, angkringan, cafe, pusat perbelanjaan atau tempat hiburan lainnya yang menyediakan fasilitas hotspot guna menarik perhatian konsumen atau masyarakat.

Pemanfaatan lainnya pada sektor ekonomi juga penting, karena sektor ini memiliki efek ganda dan dapat menggerakkan ekonomi di seluruh lapisan masyarakat yakni dengan memberikan layanan informasi dan interaksi, seperti reservasi online (hotel, paket, wisata, transportasi, dan sebagainya), sistem pembayaran online, pengelolaan database pariwisata daerah, proses interaksi, dan transaksi lainnya.

Dalam bidang pendidikan, sekolah mulai dari jenjang Sekolah Dasar hingga Perguruan Tinggi penggunaan hotspot atau internet telah menjadi bagian gaya hidup. Urgensi penggunaan tersebut dalam dunia pendidikan perlu disadari masyarakat sekolah sebagai pendukung tercapainya tujuan pendidikan Nasional. Keunggulan pemanfaatan internet atau fasilitas hotspot dalam kerangka media pengajaran oleh guru akan terlihat dari integrasi-interkoneksi lingkungan. Esensi kompetensi pemanfaatan internet siswa dapat belajar, kegiatan atau interaksi antara peserta didik dan pendidik dilakukan tidak hanya tatap muka, tetapi dapat juga dilakukan melalui media komunikasi seperti telepon, komputer, internet, e-mail, dan sebagainya.

Penerapan cyber city di kota Yogya juga membawa dampak perubahan dalam budaya kerja masyarakatnya, karena makin banyak masyarakat yang memilih untuk melakukan kerja jarak jauh atau teleworking. Selain itu, untuk mewujudkan penerapan cyber city pemerintah kota Yogya juga membangun taman kota yang berbasis IT. Keberadaan taman kota di Yogya 
yang telah memiliki jaringan internet melalui $W i-F i$ merupakan peningkatan kualitas dari ruang publik sekaligus mencerminkan perwujudan dari persiapan menuju ruang publik yang berbasis TIK. Taman sebagai ruang publik diharapkan dapat menjadi tempat bagi warga Kota Yogya untuk dapat mengembalikan fungsi ruang publik taman kota sebagai sarana kegiatan rekreasi dan melakukan interaksi sosial.

Manfaat lain yang bisa dirasakan dari terwujudnya Cyber City adalah kemudahan pelayanan publik. Tiap Pemerintah Daerah atau Pemerintah Kota beserta masyarakatnya akan termudahkan dengan memanfaatkan TI. Hal ini akan mendorong good governance, dan kepercayaan masyarakat akan meningkat seiring mudahnya pelayanan publik.

\section{KESIMPULAN}

Cyber city merupakan salah satu konsep kota modern berbasis teknologi informasi yang kini telah banyak diterapkan di sejumlah kota besar di seluruh dunia. Ini adalah konsekuensi logis dari meningkatnya kebutuhan masyarakat yang ingin mengakses informasi dan berkomunikasi dengan mudah dan cepat. Wacana Sebagai bagian dari masyarakat dunia modern, bangsa Indonesia sudah saatnya menerapkan konsep cyber city untuk memenuhi kebutuhan warganya dalam mengakses internet secara lebih luas dan tidak lagi terbatas pada kalangan tertentu saja.

Dalam rangka mewujudkan visi misi kota Yogyakarta, beberapa terobosan terus dikerjakan Pemerintah dan salah satunya pengembangan Kota Yogya sebagai cyber city. Salah satu bentuk penerapan program cyber city yang ada di kota Yogya diistilahkan dengan "Republik Hot Ngelesot". Berdasarkan hasil penelitian dapat diambil kesimpulan yaitu:

1. Kota Yogyakarta telah menyediakan layanan pendidikan berbasis teknologi informasi dan komunikasi secara online dalam rangka mendukung salah satu visi Kota Yogyakarta sebagai Kota Pelajar.

2. Membangun dan membentuk karakter masyarakat kota Yogya yang melek akan teknologi.

3. Dalam bidang ekonomi, pemanfaatan internet dapat meningkatkan dan menggerakan perekonomian masyarakat kota Yogya sebagai masyarakat yang mandiri dan kreatif dalam membangun sebuah usaha. Selain itu, manfaat internet juga dapat meningkatkan sektor 
perekonomian

pariwisata

pemerintah kota Yogya.

4. Memberikan kemudahan kepada masyarakat dalam hal pelayanan publik akan kebutuhan masyarakat terhadap suatu pelayanan informasi dan komunikasi digital yang serba cepat, efisien dan efektif. Dan juga mendukung program pemerintah provinsi yaitu Jogja Cyber Province.

\section{UCAPAN TERIMA KASIH}

Penulis mengucapkan terima kasih kepada Pemerintah Daerah Istimewa Yogyakarta, Bapak Haryanta, SH selaku kepala Biro Umum, Hubungan Masyarakat dan Protokol yang telah membantu penulis dalam proses pengumpulan data.

\section{DAFTAR PUSTAKA}

Daekin, M. 2014. Smart Cities. New York: Routledge.

Giles, D. 2003. Media Psycholgy.New Jersey: Lawrence Erlbaum Associates.

Indrajit, Eko, Ricardus. 2000, Manajemen Sistem Informasi dan Teknologi Informasi. Jakarta: PT Elex Media Komputindo

Kriyantono, Rachmat. 2006. Teknik Riset Komunikasi. Jakarta: PT Rajagrafindo Persada.

Moleong, Lexy, J. 2002. Metode Penelitian Kualitatif. Bandung: PT. Remaja Rosda Karya.
Pawito. Penelitian Komunikasi Kualitatif. LKIS Pelangi Aksara. Yogyakarta. 2008.

Rachmawati, R. 2011.ICT Based Services In Bank Sector And Its Benefit For Citizen In Yogyakarta Municipality, Indonesia.Yogyakarta: Fakultas Geografi UGM.

Ruslan, Rosady. 2010. Metodologi Penelitian Public Relations dan Komunikasi cetakan ke-5. Rajawali Pers. Jakarta.

\section{Jurnal :}

Aprilia, Rizki, Sisca \& Rachmawati, Rini. Jurnal Bumi Indonesia. Fakultas Geografi Universitas Gajah Mada, Yogyakarta. Volume 2, Nomor 3, Tahun 2013.

\section{Sumber lain :}

http://id.wikipedia.org/wiki/cyber_city (Di akses pada 01 Februari 2017). McCurtis, M., \& Wimberly, S. 2002. The Cyber City.(Di akses pada 12 Desember 2016 dari http://www1.american.edu/carmel /sw0143a/cybercities.html).

Suroso dan Adi Winanto. 2009. Pemanfaatan ICT dalam Pembelajaran dan Peningkatan Profesionalisme Guru. (Di akses pada 12 Desember 2016 dari http://pjipgsd.dikti.go.id/file.php/1 /repository/dikti/BA_DIPBPJJ_B ATCH_1/Manajemen 20Berbasis\%20Sekolah/UNIT\%2 09.pdf.) 